NASZA DERMATOLOGIA Online OUR DERMATOLOGY Online

Source of Support: Nil

Competing Interests: None
EPONYMS IN DERMATOLOGY LITERATURE LINKED TO AUSTRALIA

\author{
Khalid Al Aboud ${ }^{1}$, Ahmad Al Aboud ${ }^{2}$ \\ ${ }^{1}$ Dermatology Department, King Faisal Hospital, Makkah, Saudi Arabia \\ ${ }^{2}$ Dermatology Department, King Abdullah Medical City, Makkah, Saudi Arabia
}

Corresponding author: Dr. Khalid Al Aboud

amoa65@hotmail.com
The nomenclature in medicine including dermatology is not totally perfect. One can see many non-precise names and even misnomers.

For examples in acanthosis nigrican there is neither acanthosis neither nigricans (pigmentation), in pyogenic granuloma, there is neither pyogenic (infection) neither granuloma, and so on and so forth.

One more example is „Buruli ulcer”, which honours neither the one who discovered it, nor the place from which it was first described, nor even any significant clinical feature, and thus has no justification for ,naming rights” [1].

One author suggested that this disease be named after its main clinical feature, namely undermined subcutaneous ulcers: hence „ulcerans disease” or „ulcerans infections”, both of which are simple, descriptive and accurate [1].

For the eponymic type of nomenclature, there have always been arguments as to who should receive primacy of recognition with regard to nomenclature of a new disease or syndrome. Until now, some health care providers like eponyms while many others do not.

Some argue that, the ,possessive use of an eponym should be discontinued, since the author neither had nor owned the disorder". Yet, eponymic terms are widely used and very unlikely to be removed from medical literature.

These eponymic terms are originated from different countries around the world. In Table I [2-6], we elaborated on a selected eponyms in dermatology literature linked to Australia.

Australia is the world's area, with a population of 22.7 million. It ranks highly in many international comparisons of national performance, such as quality of life, health, education, economic freedom, and the protection of civil liberties and political rights [1]. The name Australia is derived from the Latin australis, meaning ,southern”.

Australia has the fourth highest life expectancy in the world after Iceland, Japan and Hong Kong. It has the highest rates of skin cancer in the world [1].

Among many other good things, Australia is remembered in dermatology for Australasian journal of Dermatology, an important dermatology resource, which is being published since 1951 [7]. This current title started in 1967. It was published as „Australian Journal of Dermatology”, from 1951-1966.

\begin{tabular}{|c|l|}
\hline $\begin{array}{c}\text { Eponyms in dermatology } \\
\text { literature linked to Australia }\end{array}$ & \multicolumn{1}{c|}{ Remarks } \\
\hline Munro microabscesses [2,3] & $\begin{array}{l}\text { Munro microabscesses are composed of degenerated polymorphonuclear leukocytes } \\
\text { in the horny layer and are seen in psoriasis and seborreic dermatitis. It is named after } \\
\text { William John Munro (1863-1908), (Fig. 1), an Australian dermatologist. } \\
\text { It is different from Spongiform pustules of Kagoj which are multilocular pustules } \\
\text { in the upper stratum malpighii within a sponge-like network made up of flattened } \\
\text { keratinocytes. They are seen in psoriasis, Reiter's disease, geographic tongue and } \\
\text { rarely in candidiasis. Spongiform pustules of Kagoj is named after Franz (Franjo) } \\
\text { Kogoj (1894-1983), a Slovenian-born physian. } \\
\text { Munro was born in Sidney, and graduated in Arts from Sidney University in 1880. He } \\
\text { proceeded to Edinburgh, where he graduated in Medicine in 1884 and was admitted } \\
\text { to the Royal College of Surgeons, London. He returned to Glebe, Sidney, where he } \\
\text { engaged in general practice until 1896. } \\
\text { The distinguishing features of psoriatic Munro's microabscess have been described } \\
\text { earlier by several authors before Munro (1898), first of all presumably by Ernst } \\
\text { Kromayer in 1890. Those authors might make, also, a note of spongiform pustule of } \\
\text { Kogoj (1927). }\end{array}$ \\
\hline Table I. Selected Eponyms in dermatology literature linked to Aaustralia
\end{tabular}




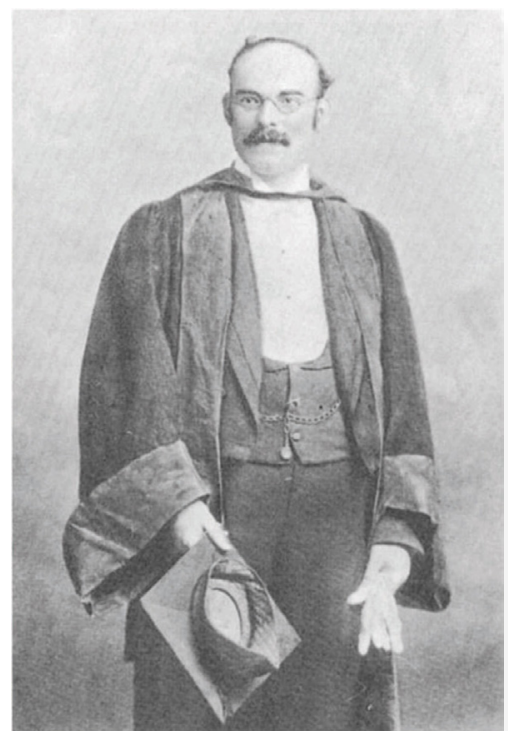

Figure 1. The legend reads, "William John Munro in the robes of a medical doctor upon graduation from Edinburgh in 1884". Reproduced from Reference number 2

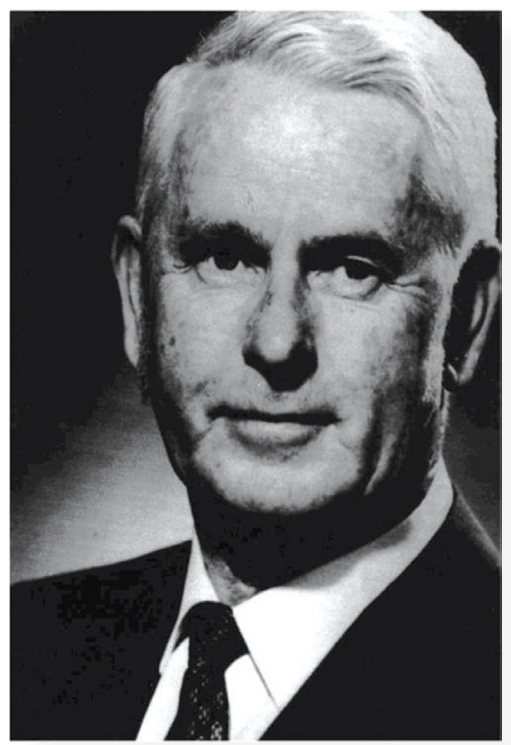

Figure 2. John P. O'Brien. Reproduced from Reference number 4

\section{Eponyms in dermatology literature linked to Australia}

O’Brien's actinic granuloma $[4,5]$

Searls ulcer [1]

\section{Remarks}

O'Brien's actinic granuloma is a rare skin disease. Controversy continues over whether it should be considered a specific condition or a form of granuloma annulare located in sun-exposed areas. It is named after John P. O’Brien (Fig. 2).

John P. O'Brien was born on May 27, 1914 in Mosman, Sydney, New South Wales, Australia. He was the foundation president of the Australasian Society of Dermatopathology, a founding member of the College of Pathologists (Australia) and its president from 1969-1971.

This is another synonym for Buruli ulcer Named after Australian practitioner, John Robert Searls (1905-1971).

Buruli ulcer is a chronic debilitating skin and soft tissue infection that can lead to permanent disfigurement and disability. It is caused by the Mycobacterium ulcerans bacterium. It is the third most common mycobacterial disease of the immunocompetent host, after tuberculosis and leprosy.

The disease was so named after Buruli County in Uganda (now called Nakasongola District), because of the many cases that occurred there in the 1960s. Also known as the Bairnsdale ulcer after Bairnsdale Country town in Victoria, Australia. Also known as Daintree ulcer, and Mossman ulcer.

Mycobacterium ulcerans has many synonyms. One of these is that used by the Mapi people in northern Uganda, but it is too much of a mouthful for general use, although it is aptly descriptive of its clinical pattern: "the ulcer that heals in vain". Similarly, the people of the Sepik District of Papua New Guinea refer to it as the "sik bilong wara Sepik". Shattock used the term "tropical ulcer type 2".

Albert Cook, a missionary doctor in Uganda, may have noted ulcerans cases in 1896, but they were first formally described in the late 1930s by Dr J.R. Searl, a general practitioner in rural Victoria, Australia, when he and his colleague, D.G. Alsop, noticed a group of patients around the town of Bairnsdale, with indolent ulcers that were resistant to the usual forms of therapy. The causative organism was isolated in 1948 by MacCallum in the Bairnsdale region of Victoria.

The disease was described widely throughout Australia, but for several decades it was known as the "Bairnsdale ulcer" and or "Searl's ulcer". "Buruli ulcer" or "Buruli disease", after the Mengo District in Buganda, came into use only in the 1960s.

There are many other geofocal synonyms for Mycobacterium ulcerans infections, reflecting its focal association with bodies of water, such as "Kumusi ulcer" and "sik bilong wara Sepik" in Papua New Guinea, from where many of the early reports came. Reports from the Congo (now DRC) go back as far as 1942. In the Congo it is known as the "Tora ulcer", the "Kasongo ulcer" and the "Kakerifu ulcer". This later name, Janssens claimed, should be the African synonym as that was the area from which the first African case was described, also by a general practitioner, Dr Lubicz. In Mexico it was named the "Mexican ulcer". 


\section{REFERENCES}

1. Radford AJ: What's in a name? Ulcerans disease: infections due to Mycobacterium ulcerans. Trans R Soc Trop Med Hyg. 2009;103:979-80.

2. Steffen C: William John Munro and Munro's abscess, and Franz Kogoj and Kogoj's spongiform pustule. Am J Dermatopathol. 2002;24:364-8

3. Lampe P: [Munro's microabscess--before Munro]. J Dtsch Dermatol Ges. 2008;6:416-20.

4. Steffen C: The man behind the eponym: John P. O'Brien--ctinic granuloma (O’Brien). Am J Dermatopathol. 2002;24:264-6.
5. Lazzarini R, Rotter A, Farias DC, Muller H: O'Brien's actinic granuloma: an unusually extensive presentation An Bras Dermatol. 2011;86:339-42.

6. Australia. [A page on the Internet].From Wikipedia, the free encyclopedia Wikipedia ${ }^{\circledR}$ is a registered trademark of the Wikimedia Foundation, Inc. [This page was last modified 2012 Sep 16; cited 2012 Sep 16] .Available at; http://en.wikipedia.org/wiki/ Australia

7. Al Aboud A, Al Aboud K: Recent Changes in Peer-Reviewed Dermatology Journal. Our Dermatol Online. 2012;3:128-30.

Copyright by Khalid Al Aboud, et al. This is an open access article distributed under the terms of the Creative Commons Attribution License, which permits unrestricted use, distribution, and reproduction in any medium, provided the original author and source are credited. 